\title{
Chronic liver disease in cattle associated with ingestion of Brachiaria spp.
}

\section{Doença hepática crônica em bovinos associada com ingestão de Brachiaria spp.}

\author{
Tatiane Cargnin Faccin ${ }^{\mathrm{I}}$ Glaucia Denise Kommers ${ }^{\mathrm{II}}$ Glauco José Nogueira de Galiza ${ }^{\mathrm{III}}$ \\ Rayane Chitolina Pupin ${ }^{\text {IV }}$ Renata Cunha Madureirav \\ Ricardo Antônio Amaral de Lemos ${ }^{\text {II }}$
}

\section{ABSTRACT}

One hundred and ninety livers condemned due to chronic disease (fibrosis) were evaluated in a bovine slaughterhouse over 12 months. Hepatic lymph nodes were also examined while still attached to livers. The major macroscopic lesion observed in the livers was moderate to severe atrophy of the left lobe associated with compensatory hypertrophy of the right lobe. Histologically, the main changes corresponded to sites of macroscopic lesions, and fibrosis was observed in all livers, along with bile duct hyperplasia and neovascularization. Masson's trichrome stain highlighted the fibrous connective tissue. Most of the livers analyzed had macrophages with foamy cytoplasm and a peripheral nucleus that infiltrated fibrotic areas. Immunohistochemistry (IHC) for macrophages with monoclonal antibody clone MAC 387 revealed that the cytoplasm of the foamy macrophages of the liver and of the hepatic lymph nodes were positively immunostained. These cells are frequently associated to the consumption of grasses of the genus Brachiaria. Although the liver gross lesions described in this study have not been previously reported in animals consuming Brachiaria, the associated changes observed histologically, such as fibrosis and infiltration of foamy macrophages, showed a new form of chronic liver disease probably associated with the consumption of this forage. The IHC technique was important to prove that the foam cells observed are macrophages.

Key words: slaughtered bovines, fibrosis, liver atrophy, foamy macrophages.

\section{RESUMO}

Cento e noventa e dois figados condenados devido à doença crônica (fibrose) foram avaliados em um abatedouro de bovinos durante 12 meses. Os linfonodos hepáticos, quando ainda estavam ligados aos figados, também foram examinados. A principal lesão macroscópica observada no figado foi moderada a acentuada atrofia do lobo esquerdo associada à hipertrofia compensatória do lobo direito. Histologicamente, as principais alterações correspondiam aos locais das lesões macroscópicas, e fibrose foi observada em todos os figados, juntamente com a hiperplasia de ductos biliares e neovascularização. A coloração de Tricrômico de Masson destacou o tecido conjuntivo fibroso. A maioria dos figados analisados apresentavam macrófagos com citoplasma espumoso $e$ um núcleo periférico que infiltravam as áreas de fibrose. A imunohistoquímica (IHQ) para macrófagos realizada com o anticorpo monoclonl clone MAC 387 revelou imunomarcação positiva no citoplasma dos macrófagos espumosos do figado e dos linfonodos hepáticos. Essas células estão frequentemente associadas ao consumo de gramíneas do gênero Brachiaria. Apesar das lesões hepáticas macroscópicas descritas neste trabalho não terem sido previamente relatadas em animais que consomem Brachiaria, as alterações histológicas associadas, como fibrose e infiltração de macrófagos espumosos, mostram uma nova forma crônica de doença hepática provavelmente associada à ingestão desta forragem. A técnica de IHQ foi importante para provar que as células espumosas observadas são macrófagos.

Palavras-chave: bovinos abatidos, fibrose, atrofia hepática, macrófagos espumosos.

IPrograma de Pós-graduação em Medicina Veterinária, Universidade Federal de Santa Maria (UFSM), Santa Maria, RS, Brasil.

"Laboratório de Patologia Veterinária, Departamento de Patologia, Centro de Ciências da Saúde, Universidade Federal de Santa Maria (UFSM), Santa Maria, RS, Brasil.

IIIFaculdade de Medicina Veterinária, Universidade de Cuiabá (UNIC), Cuiabá, MT, Brasil.

IVPrograma de Residência Profissional em Medicina Veterinária, Faculdade de Medicina Veterinária e Zootecnia (FAMEZ), Universidade Federal de Mato Grosso do Sul (UFMS), Campo Grande, MS, Brasil.

vFiscal Federal Agropecuário, Ministério da Agricultura Pecuária e Abastecimento, Campo Grande, MS, Brasil.

${ }^{\text {VI }}$ Faculdade de Medicina Veterinária e Zootecnia (FAMEZ), Universidade Federal de Mato Grosso do Sul (UFMS), Av. Senador Filinto Muller, 2443, 79074-460, Campo Grande, MS, Brasil. E-mail: ricardo.lemos@ufms.br. Corresponding author. Received 03.21.16 Approved 05.09.16 Returned by the author 07.21.16 CR-2016-0297.R1 


\section{INTRODUCTION}

The most frequent hepatic diseases encountered in slaughtered bovine are telangiectasia, hepatitis, perihepatitis (adhesions), fascioliasis, hydatidosis, tuberculosis, abscesses, and cirrhosis (LAUZER et al., 1979; MENDES \& PILATI, 2007). Studies in several Brazilian states show that the causes of liver condemnation vary according to the geographical region, because the majority of these causes, such as parasitic diseases or intoxications may vary according to the region (LAUZER et al., 1979; MENDES \& PILATI, 2007; VIEIRA et al., 2011; TESSELE et al., 2013). In the state of Mato Grosso do Sul (MS), Brazil, the condemnation of livers due to brachiaria-induced fibrosis causes significant economic losses for the meat industry due to condemnation of beef liver with an estimate annual loss of more than R\$100,000.00 in a single slaughterhouse (FACCIN et al., 2015).

Brachiaria species are the most important forage for extensively reared ruminants in the central region of Brazil, although occasionally this plant is associated with some kind of toxicity. In ruminants, the ingestion of Brachiaria can lead to hepatic lesions, photosensitivity and weight loss (RIET-CORREA et al., 2011), as well as liver cirrhosis, particularly in sheep (FACCIN et al., 2014). Foamy macrophages (FMs) are associated to the consumption of Brachiaria pastures in cattle (DRIEMEIER et al., 1999).

Although the epidemiology and clinicalpathological features of poisoning by Brachiaria are well studied in ruminants, the pathogenesis of the poison is not well understood (RIET-CORREA et al., 2011). There are very few studies on how the observed FMs are formed in the liver parenchyma of bovines with clinical signs of poisoning and also in asymptomatic animals grazing on grasses of Brachiaria genus (DRIEMEIER et al., 1998).

The objectives of this study were to characterize the pathological and immunohistochemical aspects of cattle livers condemned due to chronic disease (fibrosis) in an abattoir in MS, Brazil.

\section{MATERIALS AND METHODS}

One hundred and ninety-two livers condemned due to fibrosis were collected from beef cattle at slaughter in the municipality of Campo Grande, MS, Brazil. Livers were identified by numeric codes to recognize the batch of origin, municipality of origin, sex, age, carcass weight, and batch. Economic losses caused by this condition were detailed in another publication (FACCIN et al., 2015).

In 181 cases, the hepatic lymph nodes were still attached to the liver and were also analyzed. When the hepatic lesions were localized, a section from the lesion site and a section from another hepatic lobe without lesions were collected $(n=167)$. When the hepatic lesions were diffuse, only one section was collected. These fragments were fixed in $10 \%$ buffered formalin, processed routinely for histopathology and stained with the hematoxylin and eosin (HE). Some of the selected samples were stained with Masson's trichrome for fibrous tissue detection.

In a few selected sections of livers and hepatic lymph nodes, the immunohistochemistry (IHC) technique was employed to detect macrophages (Clone MAC 387) according to the following protocol. Upon removal of paraffin and rehydration of the tissues, the endogenous peroxidase activity was blocked with $3 \%$ hydrogen peroxide, followed by antigen retrieval with microwave in TRIS-EDTA ( $\mathrm{pH}$ 9.0) for 10min; this was followed by blocking of non-specific reactions with $5 \%$ casein solution. A monoclonal mouse anti-human myeloid/histiocyte antigen (Clone MAC 387; Dako Corp., Carpinteria, $\mathrm{CA}$; diluted 1:800), were used as the primary antibody, diluted in PBS-T, and incubated for $1 \mathrm{~h}$ at $37^{\circ} \mathrm{C}$. Tissue samples were incubated at room temperature for $30 \mathrm{~min}$ with a horseradish peroxidase (HRP)-polymer (EasyLink One - Polímero HRP, Erviegas, São Paulo, SP) and labelled by addition of liquid $\mathrm{DAB}+$ substrate-chromogen system (Dako) for 3min. Histological sections of cases with macrophages were utilized as positive control. The same sections were used as negative controls but by replacement of the primary antibody with PBS-T.

\section{RESULTS}

The bovine evaluated were from different municipalities and mesoregions of MS; 30/192 (15.63\%) bovine were from the Northern central mesoregion, 39/192 (20.31\%) from the Pantanais mesoregion, $47 / 192(24.48 \%)$ from the Southwest, and $76 / 192(39.58 \%)$ from the East.

With regards to age, $28 / 192(14,58 \%)$ of cattle were 20 month-old, $42 / 192(21,88 \%)$ were 21 24 month-old, $35 / 192(18,23 \%)$ were $25-30$ monthold, 36/192 (18,75\%) were 31-36 month-old, 49/192 $(25,52 \%)$ were $>36$ month-old. Age of two $(1,04 \%)$ cattle was not reported. The average weight of the carcasses was $271.34 \pm 36.93 \mathrm{~kg}$ and of the original 
bovine batch was $274.56 \pm 33.16 \mathrm{~kg}$. Out of 192 bovines, $173(90.1 \%)$, were male.

The main gross lesion observed in the livers condemned due to fibrosis was a moderate to severe atrophy of the left hepatic lobe with a compensatory hypertrophy of the right hepatic lobe (Figure 1A); this was observed in 94/192 (48.96\%) cases. Capsule of the left lobe was whitish (interpreted as fibrosis), and in some cases, the injury extended to the parenchyma. Whitish areas of the capsule also extended to the right lobe (Figure 1B) in 11/94 livers, and in some cases, these areas infiltrated the parenchyma, dividing the right lobe into two or more lobes (Figure 1C). In few cases, hypertrophy of the caudate process was also observed (Figure 1C).

In $36 / 192(18.75 \%)$ livers, only one focally extensive whitish depressed area was observed in the left lobe (Figure 1D) in 24 livers, in the right lobe in 10 livers, and on both the lobes in 2. In 24/192 (12.5\%) livers, lesions were multifocal. Whitish and depressed area between the right and left lobes, which also divided them, was observed in 22/192 (11.46\%) livers.

In $12 / 192$ cases $(6.25 \%)$, the lesions were punctate and whitish and were present all over the capsule and liver parenchyma. In some places, these punctuate areas were present in a multifocal to coalescing form. In 4/192 cases (2.08\%), only an adhesion was observed between the diaphragm and liver. No macroscopic changes were observed in the lymph nodes.

Histologically, the main alterations were restricted to the macroscopic lesion sites, and fibrosis, bile duct hyperplasia, and neovascularization were observed in all livers. Out of $139(72.4 \%)$ livers, 9 showed mild FMs infiltration, 39 showed moderate, and 91 showed severe infiltration, and in 53/192 $(27.6 \%)$ cases, FMs were not observed. Among the fibrotic areas described above, FMs infiltration was observed (Figure 1E). In most cases, lesions extended from the capsule to the parenchyma. Infiltrates of lymphocytes and viable hepatocytes trapped within the lesion sites, forming regenerative nodules, were often observed. In a number of samples, multinucleated giant cells and areas of hemorrhage were detected. In only one case, an eosinophilic infiltrate was observed associated with the FMs within the fibrotic area.

When gross lesions were observed on only one lobe of the liver, the histological injuries observed in the other lobe were discrete. In 41/167 cases, no FMs were detected. In the remaining samples (126/167), multifocal FMs were present and were predominantly random with minimal $(23 / 126)$, mild
(70/126), or moderate $(33 / 126)$ intensity. The other lesions also observed in these livers were periportal fibrosis, bile duct hyperplasia, and lymphocyte infiltrates, although with mild intensity. In a few cases, multinucleated giant cells were also observed.

Only 5 out of 181 hepatic lymph nodes did not present FMs (2.76\%). In 176/181 (97.24\%) lymph nodes with FMs, the distribution of those cells was multifocal $(75 / 176)$ or coalescing $(101 / 176)$, with minimal $(9 / 176)$, mild $(58 / 176)$, moderate $(86 / 176)$, or severe $(23 / 176)$ intensity. In $83 / 176$ lymph nodes, hemorrhage was observed within the FMs foci, sometimes associated with hemosiderin and eosinophil infiltration. No other findings were observed.

Masson's trichrome was used to better visualize the fibrous connective tissue in blue (Figure 1F). Immunohistochemical analysis showed foam cells with positive cytoplasmic immuno labeling in the liver (Figure 1 [ $\mathrm{Ge} \mathrm{H}]$ ) and in hepatic lymph nodes for antibody clone MAC 387. Kupffer cells (internal controls) had strong positive immuno labeling (Figure 1H). In sections in which FMs were rare or not detected by the HE staining, the immunostaining intensity was weak.

\section{DISCUSSION}

The bovine evaluated in this study were from 32 different municipalities, representing four mesoregions of MS, Brazil. The majority of the condemned livers were from males, although this selection does not represent a male predisposition for development of these types of lesions. This may be justified by the fact that this category represents a majority of the bovine population (approximately 70\%) slaughtered in this specific beef processing plant.

Most cattle $(73.45 \%)$ were $\leq 36$ months of age, and the average weight of the carcasses, from which the livers were condemned due to fibrosis, was similar to the average weight of carcasses from other slaughtered bovines of the same batch. This demonstrated that this type of localized lesion probably does not affect the weight gain of animals. This is due to the capacity of the hepatic mass readily to adapt to metabolic demands, and the liver can undergo marked atrophy due to catabolism during illness without much evidence of impaired hepatic function. Atrophy of part of the liver may be a response to pressure or to impairment of blood or bile flow. However, the functional consequences of focal hepatic atrophy are minor because the 


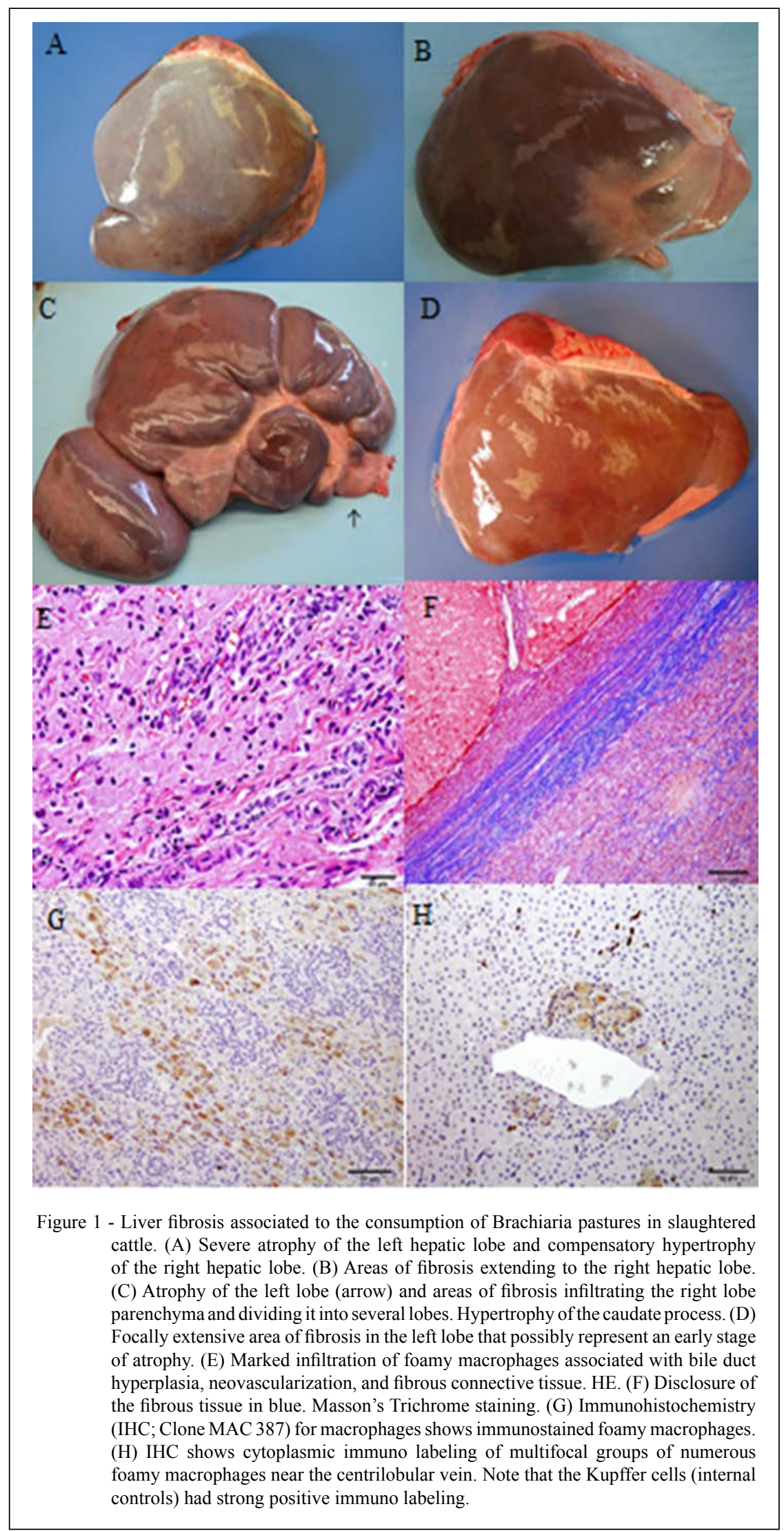

Ciência Rural, v.46, n.11, nov, 2016. 
remaining liver can adapt by compensatory hypertrophy, a process that involves replication and enlargement of hepatocytes (STALKER \& HAYES, 2007). In buffaloes, no significant difference was observed between the severity of FMs infiltration and weight of the animal when slaughtered (RIETCORREA et al., 2010).

Foamy macrophages were reported in $72.4 \%$ of hepatic lesions and in $97.24 \%$ of hepatic lymph nodes. These collections of cells are one of the hallmarks of liver induced lesions by the ingestion of Brachiaria spp. (DRIEMEIER et al., 1999) and have been detected in livers as well as in hepatic and mesenteric lymph nodes of bovines and buffaloes that are clinically healthy and grazing on this pasture (DRIEMEIER et al., 1998; GOMAR et al., 2005; RIET-CORREA et al., 2010; CAICEDO et al., 2012). Although in this study have not been seen the pasture that the cattle were consuming before slaughter, we can say that probably these foam cells are related to the consumption of Brachiaria, according to a previous study by DRIEMEIER et al. (1999). According to study by DRIEMEIER et al. (1999) with liver samples of cattle died from different causes between 1970 and 1991 and which grazed known pasture, FMs were not seen in the samples from 1970 to 1975 and were observed from 1976 on, coinciding with the introduction of B. decumbens from Australian seeds into Brazil. The correlation between FMs and ingestion of some species of Brachiaria is supported by the absence of these cells in livers of bovines slaughtered in the Brazilian states of Santa Catarina and Rio Grande do Sul (GOMAR et al., 2005; MENDES \& PILATI, 2007), where the Brachiaria spp. is poorly cultivated, and in buffaloes in the Marajó Island who graze in the native fields (RIET-CORREA et al., 2010). In this study, birefringent crystals were not observed in bile ducts, macrophages or hepatocytes. These crystals are characteristic in livers of animals with clinical signs of Brachiaria poisoning (RIETCORREA et al., 2011), but it has not been observed in asymptomatic ruminants grazing on this pasture (GOMAR et al., 2005; RIET-CORREA et al., 2010; CAICEDO et al., 2012).

The main gross lesion observed in livers condemned due to fibrosis was severe atrophy of the left hepatic lobe with hypertrophy of the right lobe. Chronic diffuse diseases of the biliary tract, such as sporidesmin poisoning and fascioliasis, can cause atrophy of the left lobe in ruminants, probably as a result of the greater difficulty in maintaining adequate biliary drainage from this lobe, whose bile ducts are longer than those of the right one in these species. Atrophy of biliary obstruction is complicated by some degree of superimposed inflammation and fibrosis (STALKER \& HAYES, 2007). Fascioliasis has not been described in the state of MS (SOUZA, 2013) and in such cases, FMs are not observed histologically (TESSELE et al., 2013). Brachiaria samples from Brazil that caused photosensitization in animals invariably contained low counts of Pithomyces chartarum and the overwhelming majority of the isolates from these samples did not produce sporidesmin (MEAGHER et al., 1996; COLLIN et al., 1998). Therefore, these facts reinforce that the main macroscopic lesion described in this paper cannot be caused by Fasciola hepatica parasitism or sporidesmin poisoning. In Colombia, it has been observed in slaughtered cattle, mononuclear cell cholangiohepatitis, foamy macrophages, moderate bile pigment accumulation, hepatocyte death, binucleated hepatocytes, moderate bile duct hyperplasia and multiple foci of mild fibrosis in portal areas caused by $\boldsymbol{B}$. decumbens (CAICEDO et al., 2012). Although, the main macroscopic lesions described in this study, characterized by severe atrophy of the left hepatic lobe (with severe fibrosis, bile duct hyperplasia, and infiltration by foamy macrophages) has not been reported previously in animals consuming Brachiaria spp. It is believed that the changes observed probably point to a form of chronic liver disease associated with the consumption of this forage. Another type of chronic poisoning was reported in bovines suffering from chronic weight loss with multifocal nodules of foamy macrophages in the intestine associated with grazing of B. decumbens (RIET-CORREA et al., 2002). Chronic poisoning by Brachiaria spp., characterized by macronodular hepatic cirrhosis with numerous foamy macrophages and birefringent crystals in the bile ducts, was already reported in one sheep with poor body conditions, exercise intolerance, and photosensitization while still a lamb (FACCIN et al., 2014). It was not possible to determine whether the bovines in this study developed photosensitization during some period in their life. The bovine studied here were in good condition when slaughtered, contrary to those in the other forms of chronic poisoning by Brachiaria in which animals lose weight (RIET-CORREA et al., 2002; FACCIN et al., 2014).

Other patterns of gross lesions observed in this study were either focally extensive or multifocal and showed histological alterations similarly to the diffuse atrophy of the left lobe; it is likely that these lesions represent an early stage of atrophy. Adhesions 
between diaphragm and liver were observed in $2.08 \%$ of the cases. Usually, these livers are not condemned due to fibrosis and could be directed for human consumption after cleansing, as no inflammatory alterations are observed (MENDES \& PILATI, 2007). Immunostaining of Kupffer cells in the liver and foam cells in the liver and the hepatic lymph node for MAC 387 antibody proved that these cells are macrophages. This antibody has been used for immuno labeling of macrophages in cattle (CABANELAS et al., 2015). In $27.6 \%$ cases with liver injury, FMs infiltration was not detected by HE staining. IHC analysis revealed only a few immunostained macrophages. In hepatic lymph nodes, immunostaining enabled detection of FMs predominantly with mild intensity. These results suggested that after the development of gross hepatic lesion, affected animals stopped consuming the toxic principle (for example, due to a period of confinement), resulting in paucity of FMs, remaining only fibrosis and bile duct proliferation.

\section{CONCLUSION}

The results of this study show a novel chronic form of liver disease in cattle characterized by severe atrophy of the left hepatic lobe in association with fibrosis and foamy macrophages. The occurrence of this new morphology of chronic disease in cattle is probably related to the ingestion of grasses of the genus Brachiaria spp. The immunohistochemistry technique was important to prove that the foam cells observed are macrophages.

\section{ACKNOWLEDGMENTS}

This research was financially supported by the Conselho Nacional de Desenvolvimento Científico e Tecnológico (CNPq number 14/2011 - Projeto Universal Proc. 483211/2012-5) and by the Instituto Nacional de Ciência e Tecnologia para o Controle das Intoxicações por Plantas (INCT/CNPq, Proc. 573534/2008-0).

\section{REFERENCES}

CABANELAS, E. et al. Histological and immunohistochemical characterization of Hypoderma lineatum (Diptera: oestridae) warbles. Veterinary Parasitology, v.212, p.361-367,2015. Available from: $<\mathrm{http}: /$ www.sciencedirect.com/science/article/pii/S0304401715002988>. Accessed: Jan. 01, 2016. doi: 10.1016/j.vetpar.2015.06.017.

CAICEDO, J.A. et al. Hepatic lesions in cattle grazing on Brachiaria decumbens in Mesetas, Meta (Colombia). Revista de la Facultad de Medicina Veterinaria y de Zootecnia, v.59, n.II, p.102-108, 2012. Available from: $<$ http://www.scielo.org.co/scielo. php?script $=$ sci_arttext\&pid=S0120-29522012000200004\&lng=pt \&nrm=iso\&tlng $=$ en $>$. Accessed: Nov. 25, 2015.
COLLIN, R.G. et al. Sporidesmin production by Pithomyces chartarum isolates from Australia, Brazil, New Zealand and Uruguay. Mycological Research, v.102, n.2, p.163-166, 1998. Available from: $<$ http://www.sciencedirect.com/science/article/pii/ S0953756208608503>. Accessed: Ago. 17, 2015. doi: 10.1017/ S0953756297004905.

DRIEMEIER, D. et al. Histologic, histochemical and ultrastructural study of livers and lymph nodes with foamy macrophages (foam cells). Pesquisa Veterinária Brasileira, v.18, n.1, p.29-34, 1998. Available from: <http://www.scielo.br/scielo.php?pid=S0100736X1998000100005\&script=sci_arttext $>$. Accessed: May. 18, 2015. doi: 10.1590/S0100-736X1998000100005.

DRIEMEIER, D. et al. Relationship between foamy macrophages in the liver of cattle and the ingestion of Brachiaria spp in Brazil. Pesquisa Veterinária Brasileira, v.19, n.2, p.79-83, 1999. Available from: <http://www.scielo.br/scielo.php?pid=S0100736X1999000200005\&script=sci_arttext $>$. Accessed: May. 18, 2015. doi: 10.1590/S0100-736X1999000200005.

FACCIN, T.C. et al. Poisoning by Brachiaria brizantha in flocks of naïve and experienced sheep. Toxicon, v.81, p.1-8, 2014. Available from: $<$ http://www.sciencedirect.com/science/article/pii/ S004101011400052X>. Accessed: May. 18, 2015. doi:10.1016/j. toxicon.2014.02.008.

FACCIN, T.C. et al. Economic losses through condemnation of bovine livers in abattoirs due to fibrosis induced by Brachiaria spp. ingestion. Pesquisa Veterinária Brasileira, v.35, n.6, p.547-551, 2015. Available from: <http://www.scielo.br/scielo. php?script $=$ sci_arttext\&pid $=$ S0100-736X2015000600547\&lng=e n\&nrm=iso\&tlng=pt $>$. Accessed: Nov. 25, 2015. doi: 10.1590/ S0100-736X2015000600010.

GOMAR, M.S. et al. Lectin histochemistry of foam cells in tissues of cattle grazing Brachiaria spp. Journal of Veterinary Medicine Series A, v.52, p.18-21, 2005. Available from: <http:// onlinelibrary.wiley.com/doi/10.1111/j.1439-0442.2004.00683.x/ epdf>. Accessed: May. 18, 2015. doi: 10.1111/j.14390442.2004.00683.x.

LAUZER, J.J. et al. Condemnation of cattle's livers in Santa Maria, RS, Brazil. Revista do Centro de Ciências Rurais. v.9, n.3, p.251-256, 1979.

MEAGHER, L.P. et al. Hepatogenous photosensitization of ruminants by Brachiaria decumbens and Panicum dichotomiflorum in the absence of sporidesmin: lithogenic saponis may be responsible. Veterinary and Human Toxicology, v.38, n.4, p.271-274, 1996.

MENDES, R.E.; PILATI, C. Morphologic study of bovine livers slaughtered in industrial slaughterhouse under State Inspection Service in West and Highland regions of Santa Catarina, Brazil. Ciência Rural, v.37, n.6, p.1728-1737, 2007. Available from: <http://www.scielo.br/pdf/cr/v37n6/ a35v37n6.pdf>. Accessed: May. 18, 2015. doi: 10.1590/ S0103-84782007000600035.

RIET-CORREA, B. et al. Brachiaria spp. poisoning of ruminants in Brazil. Pesquisa Veterinária Brasileira, v.31, n.3, p.183-192, 2011. Available from: <http://www.scielo. br/scielo.php?pid=S0100-736X2011000300001\&script $=$ sci arttext $>$. Accessed: May. 18, 2015. doi: 10.1590/S0100736X2011000300001 
RIET-CORREA, B. et al. Histologic lesions in livers and lymph nodes in buffalo (Bubalus bubalis) grazing in Brachiaria spp. pastures. Pesquisa Veterinária Brasileira, v.30, n.9, p.705711, 2010. Available from: <http://www.scielo.br/scielo. php?script $=$ sci_arttext\&pid=S0100-736X2010000900001 $>$. Accessed: May. 18, $2015 . \quad$ doi: 10.1590/S0100736 X2010000900001.

RIET-CORREA, G. et al. Wasting and death in cattle associated with chronic grazing of Brachiaria decumbens. Veterinary and Human Toxicology, v.44, n.3, p.179-180, 2002.

SOUZA, R.I.C. Estudo retrospectivo de doenças tóxicas e neurológicas em bovinos no estado de Mato Grosso do Sul. 2013. 86f. Tese (Doutorado em Ciência Animal) - Curso de Pósgraduação em Ciência Animal, Universidade Federal de Mato Grosso do Sul, MS.
STALKER, M.J.; HAYES, M.A. Liver and biliary system. In: MAXIE, M.G. Jubb, Kennedy and Palmer's pathology of domestic animals. 5.ed. St Louis: Mosby Elsevier, 2007. v.2, p.297-388.

TESSELE, B. et al. Parasitic lesions observed in cattle slaughtered for human consumption. Pesquisa Veterinária Brasileira, v.33, n.7, p.873-889, 2013. Available from: <http:// www.scielo.br/scielo.php? script $=$ sci_arttext\&pid $=\mathrm{S} 0100$ 736X2013000700008>. Accessed: May. 18, 2015. doi: 10.1590/ S0100-736X2013000700008.

VIEIRA, N.P. et al. Condemnation of bovine liver in the southern region of the State Espírito Santo, Brazil. Arquivo Brasileiro de Medicina Veterinária e Zootecnia, v.63, n.6, p.1605-1608, 2011. Available from: $<$ http://www.scielo.br/scielo.php?script=sci_artte xt\&pid=S0102-09352011000600047>. Accessed: Ago. 17, 2015. doi: 10.1590/S0102-09352011000600047. 